\title{
Migration and mental health: Japanese Brazilians in Japan and in Brazil
}

\author{
Migração e saúde mental: brasileiros descendentes \\ de japoneses no Japão e no Brasil
}

Lincoln Sakiara Miyasaka', Soraya Canasiro², Yu Abe ${ }^{3}$, Koichiro Otsuka ${ }^{4}$, Keisuke Tsuji ${ }^{5}$, Takuji Hayashi',

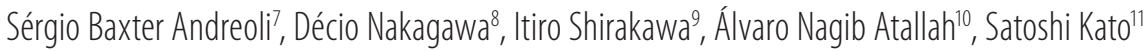

\section{RESUMO}

Objetivo: O Brasil é o país com a maior comunidade de descendentes japoneses do mundo (migração iniciada em 1908). No entanto, mais recentemente (1988) um movimento migratório em direção oposta se iniciou. Muitos desses descendentes têm migrado para o Japão a trabalho e sofrem distúrbios mentais. Alguns deles procuram tratamento no Japão, enquanto outros retornam ao Brasil para se tratarem. O objetivo do presente estudo é comparar o perfil sociodemográfico e diagnósticos dos pacientes ambulatoriais brasileiros descendentes de japoneses que permaneceram no Japão com os que retornaram ao Brasil. Método: Todos os pacientes ambulatoriais atendidos de forma consecutiva nas unidades psiquiátricas no Japão e no Brasil de abril de 1997 a abril de 2000 foram comparados. Os diagnósticos foram realizados por psiquiatras de acordo com a CID-10. Os dados sociodemográficos e os diagnósticos no Brasil e no Japão foram comparados por meio do Teste Qui-Quadrado. Resultados: $\mathrm{O}$ grupo que retornou ao Brasil era principalmente de homens, não casados, que viviam sós no Japão, tiveram uma breve estada neste país e foram classificados no grupo de esquizofrenia. O grupo no Japão era principalmente constituído de mulheres, casadas, morando com familiares ou amigos, estada longa no Japão e foram

\section{Palavras-chaves}

Migração, Japão, Brasil, brasileiros descendentes de japoneses, psiquiatria, saúde mental. classificadas no grupo de ansiedade. A regressão logística mostrou que os fatores mais significativamente associados com o grupo que retornou foram o fato de morar sós e ficarem pouco tempo no Japão ( $O R=0,93$ e 40,21, respectivamente). Conclusão: Concluímos que morar em família e ter uma rede de amigos é muito importante para a saúde mental no contexto avaliado.

\footnotetext{
1 Discipline of Urgent Medicine, Federal University of São Paulo. 2 Beneficência Nipo-Brasileira. 3 Faculty of Psychology, Meiji Gakuin University, Japan. 4 School of Nursing, Jichi Medical University, Japan.

5 Department of Human Studies, Faculty of Human Studies Musashino University, Japan. 6 Department of Neuropsychiatry, Graduate School of Medicine, Kyoto University, Japan. 7 Department of Psychiatry, Federal University of São Paulo.

8 Clínica Sunrise, Brazil.

9 Department de Psychiatry, Federal University of São Paulo, Brazil. 10 Discipline of Urgent Medicine, Federal University of São Paulo, Brazil.

11 Department of Psychiatry Jichi Medical University, Japan.
} 


\section{Key-words}

Migration, Japan, Brazil, Japanese Brazilian, psychiatry, mental health.

\section{ABSTRACT}

Objective: Brazil is the country with the largest community of Japanese descendants in the world, from a migration movement that started in 1908. However, more recently (1988), a movement in the opposite direction began. Many of these descendants went to Japan for work purposes and suffered mental distress. Some of them sought treatment in Japan, while others returned to Brazil to seek treatment. The aim of the present study was to compare the sociodemographic profile and diagnoses of Japanese Brazilian psychiatric outpatients in Japan (remaining group) and in Brazil (returning group). Method: All consecutive Japanese Brazilian outpatients who received care from the psychiatric units in Japan and Brazil from April 1997 to April 2000 were compared. The diagnoses were based on ICD-10 and were made by psychiatrists. Sociodemographic data and diagnoses in Brazil and Japan were compared by means of the Chi-Squared Test. Results: The individuals who returned to Brazil were mostly male and unmarried, had lived alone in Japan, had stayed there for short periods and were classified in the schizophrenia group. The individuals who remained in Japan were mostly female and married, were living with family or friends, had stayed there for long periods and were classified in the anxiety group. Logistic regression showed that the most significant factors associated with the returning group were that they had lived alone and stayed for short periods (OR $=0.93$ and 40.21, respectively). Conclusion: We conclude that living with a family and having a network of friends is very important for mental health in the context evaluated.

\section{INTRODUCTION}

The relationship between migration and mental health has been studied since 1880 (Odegaard, 1932). Some of the hypotheses for explaining this relationship are: the migratory process causes mental distress; subclinically ill individuals are more prone to migrate; the first two factors together cause this association (Grove, 1986); or negative life events in the country of origin, such as unemployment, family crisis and violence motivate the migratory process (Miyasaka et al., 2002).

Odegaard (1932) observed a higher number of admissions to hospital for schizophrenia among foreign-born patients than among natives. Pope et al. (1983) found an association between migration and manic-depressive illness, and Grove et al. (1986) related migration to unipolar depression. Bhugra (2004) conducted a wide-ranging review on migration and mental health and described the stages of migration and psychopathology. Escobar et al. (2000) reviewed five large-scale studies on the mental health of Mexican Americans in the United States and concluded that, despite significant socioeconomic disadvantages, Mexicoborn immigrants had better mental health profiles than did the US-born Mexican Americans. He explained that these findings might be due to a protective effect from the traditional family network, and a lower set of expectations about what would constitute "success" in America, for the Mexicoborn immigrants. On the other hand, he noted that there were high rates of substance abuse among US-born immigrants, because of easier access to such substances.

Many studies have been published concerning different ethnic groups, such as Afro-Caribbeans in Britain (Hutchinson et al., 1996; Burnett et al., 1999; Gilvarry et al., 1999), Chinese Americans in United States (Takeuchi et al., 1998) and Japanese Americans in the United States (Marsella, 1993; Newton et al., 1988; Wooden, 1988; Nagata, 1999). At this point, we will focus on the history of Japan and Brazil. A hundred years ago, Japan was facing unemployment and Brazil needed a laboring force after the abolition of slavery in 1888. Japanese immigration to Brazil began with the arrival of the ship Kasato Maru in 1908 (Handa, 1987). Almost a century later, their descendants in Brazil have reached a population of 1,228,000 people, which makes this the largest community of Japanese descendants outside of Japan (Japan-Brazil Study Center, 1990: Survey of the population of Japanese descendents living in Brazil). But the economic situation changed. Brazil faced a high rate of unemployment (16\% of the economically active population of São Paulo city in June 1997, according to <www.dieese.org.br>) and Japan had become the second biggest economy in the world. Industrial growth led to calls for Japan to be opened up for immigrants to work in the factories, because Japan had a low birth rate and a small number of young people with high education levels who did not want to work in assembly-line professions. In 1990, the Japanese government passed the Immigration Control Law Reform, which 
allowed Japanese descendants to return and work in Japan (Miyoshi, 1993; Ninomiya, 1992; Osawa, 1993). It has been estimated that there are 222,217 Japanese Brazilians living in Japan (Japan Immigration Association, 1999): these are the so-called "dekassegui", which means the people who work far away from home (Ninomiya, 1992).

In a previous study, we compared the mental health of two communities of Japanese Brazilians (one in Brazil and the other in Japan) and showed that $17.8 \%$ in Japan and 3.2\% in Brazil had a minor psychiatric disorder (Miyasaka et al., 2002). We have also analyzed the problems reported by the community in Japan (Miyasaka, 2000) and the profile of Japanese Brazilian psychiatric outpatients at a clinic in São Paulo, Brazil (Shirakawa et al., 2003).

In 1997, we started a psychiatric care service for Japanese Brazilians in three medical centers in Japan. The aim of the present study was to compare sociodemographic data and diagnoses between Japanese Brazilians who sought treatment in Japan (remaining group) and those who returned to Brazil and sought treatment in their native country (returning group).

\section{METHODS}

All consecutive Japanese Brazilian outpatients who received care from the psychiatric units in Japan and Brazil from April 1997 to April 2000 were compared. Only patients with Japanese ascendance were included. In Japan, the psychiatric services were in two medical schools (Jichi Medical School, in Tochigi province and Aichi Medical School, in Aichi province) and a clinic in Chiba province (group remaining in Japan). In Brazil, the psychiatric unit was Beneficência Nipo-Brasileira in São Paulo city, a clinic that is a national reference for caring for Japanese Brazilians (group returning to Brazil).

The diagnoses were based on ICD-10 and were made by psychiatrists. The patients' diagnoses were divided into four categories: schizophrenia (including brief psychotic disorder, schizophrenia, delusional disorder and schizoaffective disorder); depression (including major depression, dysthymia and bipolar depression); anxiety (including generalized anxiety disorder, PTSD, OCD, conversion, panic, somatization, adjustment disorder and social phobia); and other diagnoses.

Sociodemographic data and diagnoses in Brazil and Japan were compared by means of the chi-squared test (Table 1). The variables that showed significance in univariate analysis were included in logistic regression analysis. The logistic regression analysis had four models. In the first model, the dependant variable was place (Brazil) and the independent variables were sociodemographic data and diagnoses considered together (Table 2). In the second to fourth mo-
Table 1. Diagnosis and sociodemographic data for the Japanese Brazilian psychiatric outpatients in Japan and Brazil (Chi-Squared Test)

\begin{tabular}{|c|c|c|c|c|}
\hline \multicolumn{2}{|l|}{ Country } & \multirow{2}{*}{$\begin{array}{c}\text { Brazil } \\
\mathrm{n}=100(\%) \\
38(38)\end{array}$} & \multicolumn{2}{|c|}{$\begin{array}{c}\text { Japan } \\
n=107(\%)\end{array}$} \\
\hline \multirow{2}{*}{ Gender } & $\mathrm{F}$ & & $59(55.1)$ & $p<0.05$ \\
\hline & M & $62(62)$ & $48(44.9)$ & \\
\hline \multirow{2}{*}{ Age } & $10-31$ & $46(46)$ & $60(56)$ & ns \\
\hline & $32-66$ & $54(54)$ & $47(43.9)$ & \\
\hline \multirow{2}{*}{ Marital status } & Married & $17(17)$ & $60(56.1)$ & $p<0.01$ \\
\hline & Not married & $83(83)$ & $47(43.9)$ & \\
\hline \multirow{3}{*}{ Schooling } & Elementary & $40(40)$ & $32(29.9)$ & ns \\
\hline & High school & $40(40)$ & $48(44.9)$ & \\
\hline & University & $20(20)$ & $27(25.2)$ & \\
\hline \multirow{5}{*}{ Profession } & Housewife & $13(13)$ & $16(15.5)$ & $p<0.05$ \\
\hline & Student & $10(10)$ & $23(22.3)$ & \\
\hline & White-collar & $53(53)$ & $53(51.5)$ & \\
\hline & Blue-color & $16(16)$ & $10(9.7)$ & \\
\hline & Unemployed & $8(8)$ & $1(1)$ & \\
\hline \multirow{2}{*}{$\begin{array}{l}\text { Mean stay period } \\
\text { (months) }\end{array}$} & & 14 & $t=-11.24$ & $p<0.01$ \\
\hline & & & $d f=205$ & \\
\hline \multirow{2}{*}{ Speak Japanese } & No & $26(26)$ & $26(24.5)$ & ns \\
\hline & Yes & $74(74)$ & $80(75.5)$ & \\
\hline \multirow{2}{*}{ Understand Japanese } & No & $17(17)$ & $26(24.3)$ & ns \\
\hline & Yes & $82(82)$ & $81(75.7)$ & \\
\hline \multirow{2}{*}{ Living conditions } & Alone & $86(86)$ & $16(15)$ & $p<0.01$ \\
\hline & With others & $14(14)$ & $91(85)$ & \\
\hline \multirow{2}{*}{ Past psychiatric history } & Yes & $38(38)$ & $21(19.6)$ & $p<0.01$ \\
\hline & No & $62(62)$ & $86(80.4)$ & \\
\hline \multirow{4}{*}{ Diagnosis } & Schizophrenia & $45(45)$ & 14 (13.1) & $p<0.01$ \\
\hline & Depression & $30(30)$ & $36(33.6)$ & \\
\hline & Anxiety & $7(7)$ & $41(38.3)$ & \\
\hline & Others & $18(18)$ & $16(15.0)$ & \\
\hline
\end{tabular}

Table 2. Logistic regression analysis on the sociodemographic data and diagnoses associated with the patients in Brazil

\begin{tabular}{lrrrrrr}
\hline & B & SE & Wald & df & \multicolumn{1}{c}{ sig } & \multicolumn{1}{c}{ OR } \\
\hline Male & 1.092 & 0.575 & 3.61 & 1 & 0.057 & 2.979 \\
Unmarried & -0.375 & 0.637 & 0.346 & 1 & 0.556 & 0.687 \\
Lived alone & 3.694 & 0.647 & 32.571 & 1 & 0.000 & 40.215 \\
Psychiatric history & 0.82 & 0.606 & 1.831 & 1 & 0.176 & 2.270 \\
Stay period & -0.073 & 0.015 & 24.302 & 1 & 0.000 & 0.930 \\
Diagnosis & Schizophrenia & 0.771 & 0.83 & 0.863 & 1 & 0.353 \\
& Depression & 0.765 & 0.797 & 0.923 & 1 & 0.337 \\
& Anxiety & -1.239 & 0.953 & 1.692 & 1 & 0.193 \\
Constant & -0.615 & 0.891 & 0.476 & 1 & 0.490 & 0.541 \\
\hline
\end{tabular}

dels, the variable of "diagnoses" was subdivided into three new variables (depression, anxiety and schizophrenia). For depression, the individuals were divided into two groups: those with a diagnosis of depression and those without this diagnosis (including anxiety, schizophrenia and others). The same procedure was followed for the variables of schizophrenia and anxiety (these results are only in the text).

\section{RESULTS}

In Japan the age range was 13-57 and in Brazil it was 17-66. Univariate analysis showed that the individuals in Brazil were mostly male and unmarried, with a past psychiatric history. They had lived alone, had stayed for short periods in Japan, 
and were diagnosed in the schizophrenia group (Table 1). From analysis of these variables using logistic regression (Table 2), it was seen that the variables associated with the patients in Brazil that continued to be significant were short stay period and living alone (OR = 0.93 and 40.21, respectively).

By replacing the overall diagnosis with the diagnosis of depression in the logistic regression model (model 2), the variables associated with the group in Brazil were: short stay period $(B=-0.78 ; S E=0.15 ; p<0.01 ;$ odds ratio $=0.92)$; living alone $(B=3.56 ; S E=0.61 ; p<0.01$; odds ratio $=35.34)$; and male gender $(B=1.21$; $S E=0.56 ; p<0.05$; odds ratio $=3.35)$. For the diagnosis of schizophrenia (model 3), the variables associated with the group in Brazil were: short stay period $(B=0.72 ; S E=0.14 ; p<0.01$; odds ratio $=0.93)$; and living alone $(B=3.51$; $S E=0.60 ; p<0.01$; odds ratio $=33.31)$. For the diagnosis of anxiety (model 4), the variables associated with the group in Brazil were: short stay period $(B=-0.73$; $S E=0.014 ; p<0.01 ;$ odds ratio $=0.93)$, living alone $(B=3.67$; $\mathrm{SE}=0.64 ; \mathrm{p}<0.01$; odds ratio $=39.38$ ) and being anxious $(B=-1.86 ; S E=0.76 ; p<0.05$; odds ratio $=0.16)$.

\section{DISCUSSION}

The migration process has been double for the community of Japanese Brazilians. Their grandparents came from Japan facing very difficult situations both in Japan (unemployment and the First and Second World Wars) and in Brazil (hard work and disease). They did not have much opportunity to learn Portuguese, but prioritized education for their children, who learned the language and the culture, and adapted well to Brazilian society (unfortunately this process led to a communication gap between the two generations). Now, the process has been inverted. The second, third and fourth generation have been returning to Japan to work in the "three Ks": kitanai, kiken and kitsui, meaning dirty, dangerous and hard kinds of work. They do not have time to learn Japanese and face communication problems with their children too (Miyasaka, 2000).

In our study, most of the patients reported that they had good language skills but in fact their skills are at a basic level. They do not have difficulty in their daily lives but they do have difficulty in expressing their feelings and symptoms to physicians. This leads towards difficulties in doctor-patient relationships, diagnosis and treatment (Miyasaka, 2000).

Comparing the diagnoses of the groups in Japan and Brazil, we found that in Japan 38\% were classified in the anxiety group and in Brazil only 18\%. In Brazil 45\% were in the schizophrenia group and only $13.1 \%$ in Japan. Anxiety was more prevalent in the group in Japan. Long-term stay leads to adaptation to the culture, but also to a doubt about whether to remain or to return (Tsuji et al., 2001). These individuals have a choice, and this choice could be a stress factor.
It depends on the economies in Japan and Brazil. When the first goes down and the second seems to go up, the desire to return increases, but everything is uncertain and these individuals are left with feeling that they are rootless pilgrims living in camps for years.

Schizophrenia is a disabling disease and the stress of migration soon leads to a psychotic crisis that forces the patient to return to the country of origin. We do not recommend migration for individuals with schizophrenic tendencies. Fortunately, the schizophrenia group includes brief psychotic disorders, which have a better prognosis, with recovery soon after returning to the country of origin, through treatment and care in the patients' own language. These data are in accordance with published findings from a clinic in São Paulo (Shirakawa et al., 2003).

The limitation of this study is that it is descriptive and relates to cases cared for by the authors. Nonetheless, the most important finding from this study was that living alone was associated with the returning group more than any other factor was, and independently of any other factor. We noted that living with family or friends and not alone was a protection factor for psychiatric patients undergoing a process of migration. Family and community support systems are very important for promoting mental health.

\section{CONCLUSION}

The Japanese Brazilian psychiatric outpatients cared for in Brazil (returning group) were mostly male and unmarried, had lived alone in Japan, had stayed there for short periods and were classified in the schizophrenia group. In Japan (remaining group), they were mostly female and married, were living with family or friends, had stayed for a long period and were classified in the anxiety group. Logistic regression analysis showed that the most significant factors associated with the returning group (in Brazil) were that they had lived alone and stayed for short periods. We conclude that living with the family and having a network of friends are very important for mental health during a process of migration. Mental health professionals should emphasize the importance of this and encourage the building of a network of friends and support systems.

\section{REFERENCES}

Bhugra D. Migration and mental health. Acta Psychiatr Scand, 109: 243-58, 2004.

Burnett $R$ et al. The first contact of patients with schizophrenia with psychiatric services: social factors and pathways to care in a multi-ethnic population. Psychological Medicine, 29: 475-83, 1999

Escobar Jl, Nervi CH, Gara MA. Immigration and mental health: Mexican Americans in the United States. Harvard Rev Psychiatry, 8: 64-72, 2000 
Gilvarry CM et al. Life events, ethnicity and perceptions of discrimination in patients with severe mental illness. Soc Psychiatr Epidemiol, 34: 600-8, 1999.

Grove W et al. Immigration and major affective disorder. Acta Psychiatr Scand, 74: 548-52, 1986.

Handa T. 0 Imigrante Japonês: História de sua Vida no Brasil. São Paulo: T. A. Queiroz: Centro de Estudos Nipo Brasileiros; 1987.

Hutchinson $\mathrm{G}$ et al. Morbid risk of schizophrenia in first-degree relatives of white and AfricanCaribbean patients with psychosis. British Journal of Psychiatry, 169: 776-80, 1996.

Japan Immigration Association - Statistics of Foreigners in Japan, Tokyo, Japan Immigration Association, 1999

Marsella AJ. Counseling and Psychotherapy with Japanese Americans: cross-cultural considerations. Amer J Orthopsychiat, 63 (2): 200-7, 1993

Miyasaka LS. Mental Health of Japanese Brazilians. Journal of Mental Health, 46: 73-8, 2000.

Miyasaka LS et al. Mental Health of two Communities of Japanese Brazilians: a comparative study in Japan and in Brazil. Psychiatry and Clinical Neurosciences, 56: 55-64, 2002.

Miyoshi T. Manual de Lei de Imigração Japonesa - Conhecimentos Básicos sobre a Entrada e Permanência no Japão. São Paulo: Estação Liberdade; 1993.

Nagata DK, et al. Long-term effects of internment during early childhood on third-generation Japanese Americans. American Journal of Orthopsychiatry 1999; 69(1).
Newton BJ et al. Ethnic identity among Japanese-Americans in Hawaii. International I Intercultural Relations, 12: 305-15, 1988.

Ninomiya M. Dekassegui - Palestras e exposições. In: Simpósio sobre o Fenômeno Dekassegui, São Paulo, 1991. São Paulo: Estação Liberdade, Sociedade Brasileira de Cultura Japonesa; 1992.

Odegaard 0. Emigration and insanity: a study of mental disease among the Norwegian-born population of Minnesota. Acta Psychiatr Scand, 4 (suppl): 1-206, 1932.

Osawa M. Transformação estrutural e relações industriais no mercado de trabalho japonês. In: Hirata H (org.). Sobre o Modelo Japonês. Edusp/ACBJ, p. 163-88, São Paulo, 1993.

Pope HG et al. Migration and manic-depressive illness. Comp Psychiatry, 24: 158-65, 1983.

Shirakawa I et al. Emigration and mental disorders of Brazilians in Japan. J Bras Psiquiatr, 52(1): $75-80,2003$.

Takeuchi DT et al. Lifetime and twelve-month prevalence rates of major depressive episodes and dysthymia among Chinese americans in Los Angeles. Am J Psychiatry 1998; 155:10.

Tsuji K et al. Panic disorder cases in Japanese-Brazilians in Japan: their ethnic and cultural confusion. Psychiatry and Clinical Neuroscience, 55: 127-30, 2001.

Wooden WS, Leon JJ, Toshima MT. Ethnic identity among sansei and yonsei church affiliated youth in Los Angeles and Honolulu. Psychological Reports, 62: 268-70, 1988. 